\title{
Effects of diverse doses of Lead (Pb) on different growth attributes of Zea-Mays L.
}

\author{
Abrar Hussain ${ }^{1}$, Nabila Abbas ${ }^{1}$, Fahim Arshad ${ }^{2}$, Muhammad Akram $^{3}$, Zafar Iqbal Khan ${ }^{4}$, \\ Kafeel Ahmad ${ }^{4}$, Muhammad Mansha ${ }^{1}$, Farhad Mirzaei ${ }^{5^{*}}$ \\ ${ }^{1}$ Division of Science and Technology, University of Education, Lahore, Pakistan \\ ${ }^{2}$ Department of Botany, University of Education, Okara Campus, Okara, Pakistan \\ ${ }^{3}$ Department of Botany, University of the Punjab, Lahore, Pakistan \\ ${ }^{4}$ Department of Biological Sciences, University of Sargodha, Sargodha, Pakistan \\ ${ }^{5}$ Department of Animal Production Management, Animal Science Research Institute of Iran, Karaj, Iran; \\ *Corresponding Author: farmir2001@gmail.com
}

Received 11 September 2012; revised 1 March 2013; accepted 2 May 2013

Copyright (c) 2013 Abrar Hussain et al. This is an open access article distributed under the Creative Commons Attribution License, which permits unrestricted use, distribution, and reproduction in any medium, provided the original work is properly cited.

\begin{abstract}
The aim of the investigation was to determine the potential effect of lead on maize growth. Lead is considered as important potent environmental contaminant. Various ecological, environmental and evolutionary processes in the microsphere are disrupted because of lead toxicity to the microbial community. The effects of Lead Nitrate $\left(\mathrm{Pb}\left(\mathrm{No}_{3}\right)_{2}\right)$ as heavy metal on germination, early growth seedling, root-shoot length, root-shoot fresh and dry weights, total protein content and the uptake of lead by roots and shoots of Zea-mays were investigated. All of the parameters were reduced by the increased lead concentrations. Such growth retardation was due to metals toxicity that resulted in damages to various physiological and biochemical processes.
\end{abstract}

Keywords: Lead Uptake; Zea-Mays L.; Early Seedling Growth

\section{INTRODUCTION}

Heavy metals (HM) act as essential plant micronutrients however, excess amount of these contents become toxic pollutants [1]. Beyond threshold levels, heavy metals (HM) are transformed into contaminants. An inhibition of plant growth was also reported through the use of HM like Pd, Zn, Cu, and Cd [2]. Their release creates pollution into the atmosphere [3] and hence these are potential hazard for plant growth and development [2]. They produce toxic affects upon plants, animals as well as human health $[4,5]$. Toxic heavy metals concentrated in the plant tissues comes from the common practices of sewage and industrial discharge on agricultural land.

Lead is considered as important potent environmental contaminant [6]. Various ecological, environmental and evolutionary processes in the microsphere are disrupted because of lead toxicity to the microbial community [7, 8]. It is commonly used in fertilizers, batteries, chemicals and ceramics, in different products like pottery, gasoline, lead glass, pesticides, paints, hair dyes, rubber toys and newsprint. Major lead content in the soil comes from weathering of geological rock formations, lead mine's discharge, automobile exhausts, industrial applications, smelting operations, fertilizer impurities, use of lead arsenate in metal plating and finishing operations, tetramethyl lead applications as anti knocking agent in petrol [9] and plants obtain lead from such agencies [1]. Increase in lead concentration in cultivated soils is detected in close proximity to industrial sites.

Zea-mays L. as one of the most important cereal crops in the world and ranks third most significant cash crop of Pakistan [10]. It is an important aspect to understand the potential capacity in metals uptake and distribution and its effects on maize growth. Leaves of Zea-mays indicate significant quantity of accumulation and further translocation of lead occurring in concentration dependent manner. Accumulation of lead in leaves depends upon its absorption from the aerial sources. Leaf morphology also contributes a lot for its intake. The Zea-mays seedlings showed strong inhibition of primary root growth with the applications of lead [11]. The lead toxicity causes cessation of root growth which was accompanied by the inhibition of growth at root tips [12]. Such observations were confirmed by histochemical and electron microscopic 
studies. Heavy metals like lead may form complex with the synthetic chelate EDTA, thus are enhancing their absorption capability by soil particles. Through this process, heavy metals can be removed from contaminated water. $\mathrm{K}^{+}$ions leakage from root cells of Zea-mays is also attributed to lead toxicity [13].

Lead inhibits water imbalance, disturbed mineral nutrition, enzyme activities, change in hormonal status and membrane permeability alteration. Lead at high concentrations inhibits cellular activities thus causing cell death [14]. Increased lead concentration hampers the synthesis of chlorophyll because of impaired uptake of Iron and Magnesium through plants. The photosynthetic apparatus is damaged due to its affinity for protein $\mathrm{N}$ - and $\mathrm{S}$ ligands. At higher concentrations of lead, inhibition of respiration is observed. The remediation of lead affected sites is carried out by relatively narrow range of engineering based technologies [15]. The rhizofiltration and phytoremediation provide better horizons for the utilization of such technique for the clean-up of lead contaminated soils.

The main objective of the present study was to investigate Lead accumulation in Zea-mays to evaluate the effects of lead toxicity on protein contents and to determine its effects on different growth parameters like seed germination, root and shoot length, root and shoot fresh and dry weight The study also throws light in understanding the capacity of Zea-mays in metal uptake and distribution and its effects on the growth of maize.

\section{MATERIAL AND METHODS}

The certified seeds of Zea-mays were obtained from Punjab Seed Corporation, Lahore. Seeds were washed thoroughly under running tap water and finally with distilled water before sowing. Six concentrations of metal salt (Lead Nitrate $\left.\mathrm{Pb}\left(\mathrm{No}_{3}\right)_{2}\right)$ i.e., Control (0.0 mM), 01, 25, 50, 100, 200, $500 \mathrm{mM}$ were prepared, respectively. Pots $(15 \times 3 \mathrm{~cm})$ were sterilized and filled with soil. Ten sterilized seeds were sown in each pot and $10 \mathrm{ml}$ of varied Lead nitrate concentrations was added to each pot at the time of sowing. Pots were kept in dark for 72 hours for germination at normal atmospheric temperature and pressure. After three days of germination, pots were then shifted to light (8000 - 10,000 Lux). The seedlings growth was observed for 14 days. Three replicates were used per treatment per experiment and experiment was repeated thrice. Data of seed germination root and shoot length, fresh and dry weight, total protein contents, lead uptake by root and shoot was recorded of 14-day old seedlings. Analysis of data and statistics was carried out as reported in an earlier study. Total Proteins was estimated through Kjeldahl's method in accordance with "official methods of analysis".
Another batch of 14 days old seedlings grown in various concentration of lead were used for estimation of metals content in root and shoot parts. Lead contents were estimated through ashing of plant material. Oven dried samples of roots and shoots were taken in porcelain crucibles (in duplicates). Samples were heated slowly at $450^{\circ} \mathrm{C}-500^{\circ} \mathrm{C}$ in muffle furnace and held at the same temperature for 5 - 7 hours till white ash was obtained. Samples showing any black residue were wetted with a few drops of conc. nitric acid, heated on a burner to eliminate nitric acid fumes and kept in the furnace for another two hours till the ash turned white. The ash was dissolved in $5 \mathrm{~m} 1$ of $6 \mathrm{~N} \mathrm{HCl}$, heated to dissolve any other remains. Acid washed filter paper was used for filtering solution followed by washing with hot distilled water. Final volume was made $100 \mathrm{ml}$ by adding distilled water. Determinations of Lead were carried out on a Hitachi Model. 170-10 atomic absorption spectrophotometer equipped with hollow cathode lamp of magnesium, operated at $217 \mathrm{~nm}$. Lead contents were calculated by comparison with the standard treatments with same amount of reagent i.e., $5 \mathrm{ml}$ of $6 \mathrm{~N} \mathrm{HCl}$ as for sample.

\section{RESULTS}

Lead had inhibitory effect on percentage germination. There was a continuous decrease in the percentage germination with the increase of Lead concentration. At 1.0 $\mathrm{mM}$ concentration, it was decreased by $10 \%$ while it reached upto $100 \%$ at $500 \mathrm{mM}$. All decreases were significant in relation to control. Lead produced deleterious effects on seedling growth. A steady decline in the seedling growth was observed with the increase in lead concentration. Shoot length was decreased at all concentrations, even the lowest treatment of $1.0 \mathrm{mM}$ reduced shoot growth by $12.07 \%$ while at $200 \mathrm{mM}$ the percentage decrease over control was up to $95 \%$. A reduction in root length was also prevalent comparable to the shoot length. A significant sharp decrease (97.74\%) was observed at 200 mM compared to control (Table 1, Figure 1).

The results were similar as that of drastic effects of lead upon the germination and growth of Zea-mays. Both fresh weight and dry weight of the seedling demonstrated

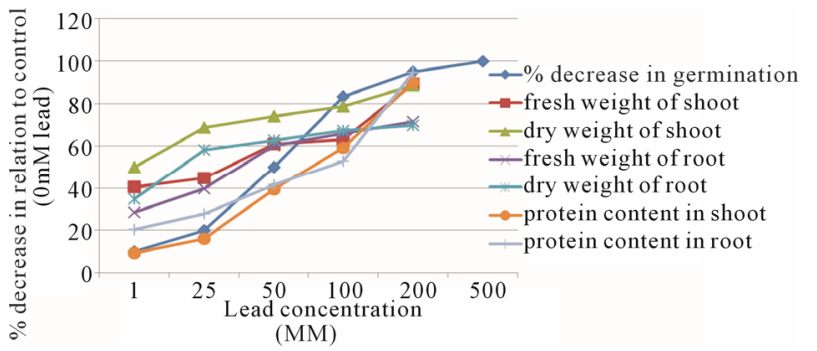

Figure 1. \% decrease in growth parameters in different concentrations of lead. 
the continuous reduction in all concentrations as compared to the control. The relative decrease at $200 \mathrm{mM}$ was $89.37 \%$ for fresh weight of shoot and $71.6 \%$ for fresh weight of root. Dry weight of shoot and root showed decrease at $1.0 \mathrm{mM}$ treatment, with the reduction in shoot dry weight (50\%) compared to root (34.89\%) in relation to control (Table 2, Figure 1).

The effect of lead on total protein content of shoot and root varied. In shoots, the total proteins were increased at $1.0 \mathrm{mM}$ while decreased at $25-500 \mathrm{mM}$. At $1.0 \mathrm{mM}$ concentration, the reduction in protein content in shoot was $9.13 \%$ while $20.34 \%$ in root in relation to control (Table 3, Figure 1). Table 3 reveals that the total uptake of $\mathrm{Pb}$ was directly proportional to the amount of lead provided to the seedlings.

\section{DISCUSSION}

The present study is confined to determine the effect of Lead Nitrate on germination, total protein content and the uptake of lead by roots and shoots of Zea-mays.The reduction in plant growth is also attributed to excessive accumulation of lead in the soils. The decrease in seed germination is attributed by the heavy metal treatment $[16,17]$. Reduced seed germination is observed in corn treated with 20, 50, 100 and $200 \mu \mathrm{g} / \mathrm{ml}$ lead acetate [18].

Table 1. Effects of $\mathrm{Pb}\left(\mathrm{NO}_{3}\right)_{2}$ on seed germination, length and fresh weight of shoot and root of 14-days old seedlings of Zea-mays L.

\begin{tabular}{|c|c|c|c|c|c|}
\hline Conc. of $\mathrm{Pb}\left(\mathrm{NO}_{3}\right)_{2}$ in $\mathrm{mM}$ & Mean \% Germination & $\begin{array}{l}\text { Mean length of shoot } \\
\text { (cm/seedling) }\end{array}$ & $\begin{array}{l}\text { Mean length of root } \\
\text { (cm/seedling) }\end{array}$ & $\begin{array}{l}\text { Mean fresh weight of } \\
\text { shoot (g/seedling) }\end{array}$ & $\begin{array}{l}\text { Mean fresh weight of } \\
\text { root (g/seedling) }\end{array}$ \\
\hline 0.0 & $100^{\mathrm{a}} \pm 0$ & $32.90^{\mathrm{a}} \pm 1.168$ & $22.10^{\mathrm{a}} \pm 1.861$ & $1.41^{\mathrm{a}} \pm 0.060$ & $0.88^{\mathrm{a}} \pm 0.0441$ \\
\hline 1.0 & $90^{\mathrm{b}} \pm 0$ & $29.40^{\mathrm{b}} \pm 0.306$ & $19.20^{\mathrm{a}} \pm 0.493$ & $0.84^{\mathrm{b}} \pm 0.029$ & $0.63^{\mathrm{b}} \pm 0.0115$ \\
\hline 25 & $80^{c} \pm 0$ & $20.63^{\mathrm{c}} \pm 1.646$ & $12.96^{\mathrm{b}} \pm 1.241$ & $0.78^{\mathrm{c}} \pm 0.018$ & $0.53^{\mathrm{c}} \pm 0.1763$ \\
\hline 50 & $50^{\mathrm{d}} \pm 0$ & $18.27^{\mathrm{d}} \pm 0.498$ & $9.06^{\mathrm{c}} \pm 0.384$ & $0.55^{\mathrm{d}} \pm 0.076$ & $0.35^{\mathrm{d}} \pm 0.0233$ \\
\hline 100 & $16.66^{\mathrm{e}} \pm 3.333$ & $6.50^{\mathrm{e}} \pm 1.656$ & $3.53^{d} \pm 0.284$ & $0.52^{\mathrm{d}} \pm 0.015$ & $0.30^{\mathrm{d}} \pm 0.0288$ \\
\hline 200 & $5.00^{f} \pm 2.511$ & $1.13^{\mathrm{f}} \pm 0.612$ & $0.50^{\mathrm{e}} \pm 0.288$ & $0.15^{\mathrm{e}} \pm 0.026$ & $0.25^{\mathrm{e}} \pm 0.0202$ \\
\hline 500 & & & No Germination & & \\
\hline
\end{tabular}

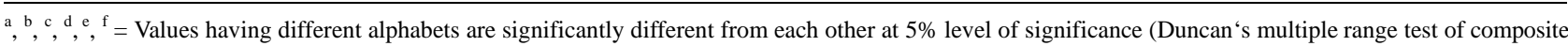
mean).

Table 2. Effect of $\mathrm{Pb}\left(\mathrm{NO}_{3}\right)_{2}$ on dry weight and protein content of shoot and root of 14-days old seedlings of Zea-mays L.

\begin{tabular}{|c|c|c|c|c|}
\hline Conc. of $\mathrm{Pb}\left(\mathrm{NO}_{3}\right)_{2} \mathrm{mM}$ & $\begin{array}{c}\text { Mean dry weight shoot } \\
\text { (g/seedling) }\end{array}$ & $\begin{array}{l}\text { Mean dry weight of } \\
\text { root/seedling (g) }\end{array}$ & $\begin{array}{l}\text { Protein in g/dry } \\
\text { weight of shoots }\end{array}$ & $\begin{array}{l}\text { Protein in g/dry } \\
\text { weight of roots }\end{array}$ \\
\hline 0.0 & $1.12^{\mathrm{a}} \pm 0.015$ & $0.43^{\mathrm{a}} \pm 0.01667$ & $29.80^{\mathrm{a}} \pm 0.057$ & $18.83^{\mathrm{a}} \pm 0.0333$ \\
\hline 1.0 & $0.56^{\mathrm{b}} \pm 0.088$ & $0.28^{\mathrm{b}} \pm 0.01667$ & $27.08^{\mathrm{b}} \pm 0.005$ & $15.00^{\mathrm{b}} \pm 0.1154$ \\
\hline 25 & $0.35^{\mathrm{c}} \pm 0.028$ & $0.18^{\mathrm{c}} \pm 0.01333$ & $25.05^{\mathrm{c}} \pm 0.011$ & $13.63^{\mathrm{c}} \pm 0.1905$ \\
\hline 50 & $0.29^{\mathrm{d}} \pm 0.026$ & $0.16^{\mathrm{d}} \pm 0.0333$ & $18.11^{\mathrm{d}} \pm 0.034$ & $11.00^{\mathrm{d}} \pm 0.1732$ \\
\hline 100 & $0.24^{\mathrm{d}} \pm 0.023$ & $0.14^{\mathrm{e}} \pm 0.00667$ & $12.13^{\mathrm{e}} \pm 0.028$ & $8.90^{\mathrm{e}} \pm 0.2886$ \\
\hline 200 & $0.13^{\mathrm{e}} \pm 0.015$ & $0.13^{\mathrm{f}} \pm 0.01000$ & $3.00^{f} \pm 0.057$ & $1.02^{\mathrm{f}} \pm 0.0057$ \\
\hline
\end{tabular}

a , b , c , d e , ${ }^{\text {f }}=$ Values having different alphabets are significantly different from each other at 5\% level of significance (Duncan's multiple range test of composite mean).

Table 3. Uptake of $\mathrm{Pb}\left(\mathrm{NO}_{3}\right)_{2}$ through shoots of 14-day old seedlings of Zea-mays L.

\begin{tabular}{|c|c|c|c|c|}
\hline Conc. of $\mathrm{Pb}\left(\mathrm{NO}_{3}\right)_{2} \mathrm{mM}$ & Uptake of Pb by shoots in ppm & Absorption & Uptake of $\mathrm{Pb}$ by roots in $\mathrm{ppm}$ & Absorption \\
\hline 0.0 & $0.3942 \mathrm{ppm}$ & 0.001 & 0.3942 ppm & 0.0013 \\
\hline 1.0 & $0.5710 \mathrm{ppm}$ & 0.0056 & $0.5710 \mathrm{ppm}$ & 0.0076 \\
\hline 25 & 1.0523 ppm & 0.0266 & 1.0523 ppm & 0.0376 \\
\hline 50 & $1.1051 \mathrm{ppm}$ & 0.3208 & $1.1051 \mathrm{ppm}$ & 0.5908 \\
\hline 200 & 1.4569 ppm & 0.7108 & 1.4569 ppm & 0.8108 \\
\hline 500 & 0.0 & 0.0 & 0.0 & 0.0 \\
\hline
\end{tabular}


Overall germination observed was greatly suppressed at all lead treatments. A sharp decrease in crop productivity in soils contaminated with lead poses a serious problem for agriculture. Lead toxicity indicates decreased dry mass of shoots and root and percentage germination [19]. Present study, revealed that the root-shoot length showed inhibition in seed germination at all lead concentrations. Fresh and dry weights of both roots and shoots were also reduced at all treatments. Lead contents decrease germination index, tolerance index, germination percent, root/ shoot length and dry mass of roots and shoots [20]. Reduction in dry matter yield of Zea-mays was also reported. The effects of lead depend on concentration, soil properties, type of soil and plant species. The total protein content of shoots increased at lower concentration of lead followed by reduction at higher concentrations. An increase in concentration of lead cause decrease of protein contents in roots (Figure 1). Many of the physiological processes, such as chlorophyll synthesis, photosynthetic rate, respiration, and protein level are inhibited due to heavy metals as evaluated by Iqbal et al. [21]. An increase in uptake of lead occurs up to certain concentration i.e., $200 \mathrm{mM}$. Beyond this limit the lead concentration decreased in both roots and shoots. The growth inhibition on a priori basis results from damage to physiological and biochemical processes.

\section{CONCLUSION}

The aim of the investigation was to determine the potential of lead to effect on maize growth. Lead is considered as important potent environmental contaminant. Various ecological, environmental and evolutionary processes in the microsphere are disrupted because of lead toxicity to the microbial community. It is concluded that, the root-shoot length showed inhibition in seed germination at all lead concentrations. Fresh and dry weights of both roots and shoots were also reduced at all treatments.

\section{REFERENCES}

[1] Kabir, M., Iqbal, M.Z. and Shafiq, M. (2009) Effects of Lead on seedling Growth of Thespesia populnea L., Advances in Environmental Biology, 3, 184-190.

[2] Iqbal, M. and Mehmood, T. (1991) Influence of cadmium toxicity on germination and growth of some common trees. Pakistan Journal of Science and Industrial Research, 34, 140-142.

[3] Oancea, S., Foca, N. and Airinei, A. (2005) Effects of heavy metals on plant growth and photosynthetic activity.

[4] Jarup, L. (2003) Hazard of heavy metal contamination. Brazilian Medical Bulletin, 68, 167-182.

[5] Azevedo, R.A. and Lea, P.J. (2005) Toxic metals in plants. Brazilian Journal of Plant Physiology, 17, 53-64.

[6] Chaney, R.L. and Ryan, J.A. (1994) Risk based standards for arsenic lead and cadmium in urban soils. Dechema,
Frankfurt.

[7] Brynhildsen, L. and Rosswall, T. (1997) Effects of metals on the microbial mineralization of organic acids. Water, Air, and Soil Pollution, 94, 45-57.

[8] Nagajyoti, P.C., Dinakar, N., Prasad, T.N.V.K.V., Suresh, C. and Damodharam, T. (2008) Heavy metal toxicity; Industrial effluent effect on groundnut (Arachis hypogaea L.) seedlings. Journal of Applied Science Research, 4, 110-121.

[9] Sharma, P. and Dubey, R.S. (2005) Lead toxicity in plants. Brazilian Journal of Plant Physiology, 17, 35-52.

[10] Stephen, P.L., Zhu, X.G., Naidu, S.L. and Donald, R. (2006) Can improvement in photosynthesis increase crop yield? Plant cell and Environment, 29, 315-519.

[11] Obroucheva, N.V., Bystrova, E.I., Ivanov, V.B., Anupova, O.V. and Seregin, I.V. (1998) Root growth responses to lead in young maize seedlings. Plant Soil, 200, 55-61.

[12] Eun, S.O., Youn, H.S. and Lee, Y. (2000) Lead disturbs microtubule organization in the root meristem of Zea mays, Physiologia Plantarum, 103, 665-702.

[13] Malkowski, E., Kita, A., Galas, W., Karez, W. and Michael, K. (2002) Lead distribution in corn seedlings (Zea-mays L.) and its effect on growth and the concentration of potassium and calcium, Plant Growth Regulators, 37, 69-76.

[14] Seregin, I.V. and Ivaniov, V.B. (2001) Physiological aspects of cadmium and lead toxic effects on higher plants, Russian Journal of Plant Physiology, 48, 606-630.

[15] Salt, D.E., Blaylock, M., Kumar, P.B.A.N., Dushenkov, V., Ensley, B.D., Chet, I. and Raskin, I. (1995) Phytoremediation: A novel strategy for the removal of toxic metals from the environment using plants, Biotechnology, 13, 468-475.

[16] Jamal, S.N., Iqbal, M.Z. and Athar, M. (2006) Effect of aluminum and chromium on the growth and germination of mesquite (Prosopis juliflora (Swartz.) DC). International Journal of Environmental Science and Technology, 3, 173-176.

[17] Mahmood, S., Hussain, A., Saeed, Z. and Athar, M. (2005) Germination and seedling growth of corn (Zea-mays L.) under varying levels of copper and zinc. International Journal of Environmental Science and Technology, 2, 269-274.

[18] Kalimuthu, K. and Siva, S.R. (1990) Physiological effects of heavy metals on Zea-mays (Maize) seedlings, Indian Journal of Plant Physiology, 33, 242-244.

[19] Munzuroglu, O. and Geckil, H. (2002) Effects of metals seed germination, root elongationand coleoptiles and hypocotyls growth in Triticum aestivum and Cucumis sativus. Archives of Environmental Contamination and Toxicology, 43, 61-73.

[20] Mishra, A. and Choudhari, M.A. (1998) Amelioration of lead and mercury effects on germination and rice seedling growth by antioxidants. Biologia Plantarum, 41, 469473.

[21] Iqbal, J., Hussain, A. Din, S. and Salariya, A.M. (1991) Cadmium uptake and distribution in young pea seedlings and its effect on growth. Acta Scientica, 1, 37-46. 